\title{
The impact of IT investments and intellectual capital on firms’ performance
}

\author{
Meysam Ghaderi ${ }^{\mathrm{a}}$, Mohsen Hamidian ${ }^{\mathbf{b}^{*}}$ and Hosein Jabari
}

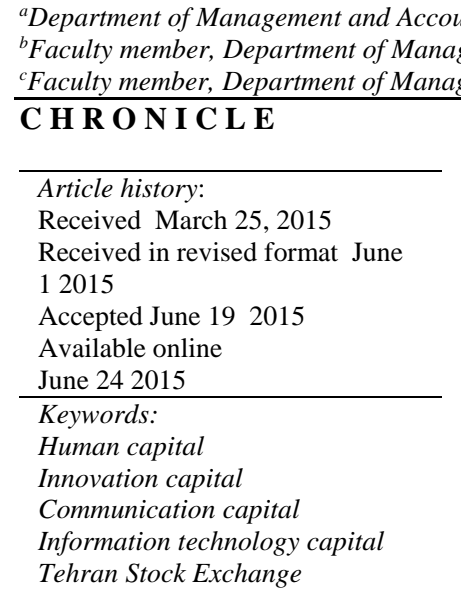

\section{Introduction}

Human resources play essential role on development and success of any financial firm and there are various studies on learning more about different aspects of human resources on firms' success (Brown et al., 1997; Watts \& Zimmerman, 1990; Blundell et al., 1999; Rhodes-Kropf et al., 2005; Badertscher, 2011). Arvanitis and Loukis (2009) investigated the effects of information and communication technologies, human capital, workplace organization and labour productivity on firms' performance. Lin et al. (2015) decomposed a firm's unexpected stock returns into intellectual capital news and expected return news and developed a variance decomposition model to analyze the parameters that cause shocks to stock returns and excess stock returns. They also split intellectual capital into recorded and unrecorded intellectual capital, and studied the value relevance of expected return news and recorded and unrecorded intellectual capital news. Wang and Chang (2005) studied the effect of intellectual capital elements on business performance, as well as the relationship among intellectual capital elements from a cause-effect perspective. They reported that intellectual capital elements

\footnotetext{
* Corresponding author.
}

E-mail address: hamidian_2002@yahoo.com (M. Hamidian) 
directly influence on business performance, with the exception of human capital. Human capital, in their survey, indirectly affected performance through the other three elements including innovation capital, process capital, and customer capital. There was also a cause-effect relationship among four elements of intellectual capital. Human capital could influence on innovation capital and process capital. Innovation capital could also influence on process capital, which in turn impact on customer capital. Finally, customer capital could also contribute to performance. Bontis and Fitz-Enz (2002) explained the results of a ground-breaking study, which measured the antecedents and consequents of effective human capital management. The study yielded a holistic causal map that integrated builds from the fields of intellectual capital, knowledge management, human resources, organizational behaviour, information technology and accounting.

Lööf and Heshmati (2002) presented a study of knowledge capital and performance heterogeneity at organizational level. They applied new econometric techniques to extensive data on innovation and innovative activities in Swedish manufacturing firm. They reported that knowledge capital, defined as the ratio of innovation sales to total sales, was a significant factor contributing to performance heterogeneity among companies. This relationship holds true even when we control for human capital, kind of output, company size, and the entry, merger, partial closure or exit of firms. In addition, knowledge capital rises with innovation input, the firm's internal knowledge for innovation, and cooperation on innovation with domestic universities.

\section{The proposed study}

This paper presents an empirical study to determine the effects of four different factors including human capital, innovation capital, communication capital and information technology capital on firms' return. The study selects the information of 50 selected firms from Tehran Stock Exchange over the period 2007-2013. The main hypothesis of the survey is as follows,

Main hypothesis: There is a meaningful relationship between information technology (IT)/intellectual capital and firms' return.

The main hypothesis of the survey is examined using the following four sub-hypotheses,

1. There is a meaningful relationship between information technology capital and firms' return.

2. There is a meaningful relationship between organizational capital and firms' return.

3. There is a meaningful relationship between communication capital and firms' return.

4. There is a meaningful relationship between innovation capital and firms' return.

The sample size was selected from Tehran Stock Exchange under some conditions. First, all firms must be accepted on exchange prior to year 2009. Second, they all must maintain the same fiscal calendar. Third, there must be no change on their fiscal calendar and finally, all required data must be available. The following four regression models are used to examine the hypotheses of the survey.

$$
\begin{aligned}
& \mathrm{R}_{\mathrm{it}+1}=\beta_{0}+\beta_{1} \text { IT Capital }_{\mathrm{it}}+\beta_{2} \text { Organization Capital }_{\mathrm{it}}+\beta_{3} \text { Relational Capital }_{\mathrm{it}}+\beta_{4} \text { R\&D Capital }_{\mathrm{it}}+ \\
& \beta_{5} \operatorname{Lev}_{\text {it }}+\beta_{6} \text { Age }_{\text {it }}+\beta_{7} \text { SIZE }_{\text {it }}+\beta_{8} \text { Invest }_{\text {it }}+\varepsilon_{i t} \text {, } \\
& \mathrm{R}_{\mathrm{it}+1}=\beta_{0}+\beta_{1} \text { IT Capital } i t+\beta_{2} \text { Relational Capital }_{i t}+\beta_{3} \text { Lev }_{i t}+\beta_{4} \text { Age }_{i t}+\beta_{5} \text { Size }_{i t}+\beta_{6} \\
& \text { Invest }_{i t}+\varepsilon_{i t} \text {, } \\
& \mathrm{R}_{\mathrm{it}+1}=\beta_{0}+\beta_{1} \text { IT Capital } \text { Cat }_{i}+\beta_{2} \mathrm{R} \& D \text { Capital }_{\mathrm{it}}+\beta_{3} \text { Lev }_{i t}+\beta_{4} \text { Age }_{i t}+\beta_{5} \text { SIZE }_{i t}+\beta_{6} \text { Invest }_{i t} \\
& +\varepsilon_{i t} \\
& \mathrm{R}_{\mathrm{it}+1}=\beta_{0}+\beta_{1} \text { IT } \text { Capital }_{i t}+\beta_{2} \text { Organzation Capital }_{\mathrm{it}}+\beta_{3} \text { Lev }_{i t}+\beta_{4} \text { Age }_{i t}+\beta_{5} \text { SIZE }_{i t}+ \\
& \beta_{6} \text { Invest }_{i t}+\varepsilon_{i t} \text {. }
\end{aligned}
$$


Here, $\mathrm{R}_{\mathrm{it}+1}$ for all four models represents firm return as dependent variable, which is calculated as follows,

$$
R_{i t}=\frac{P_{i t}-P_{i o}+D P S_{i t}}{P_{i o}},
$$

where $P_{i t}, P_{i o}$ and $D P S_{i t}$ represent year end price, opening year price and dividend per share, respectively. In the event that a firm increases its capital, the return is calculated as follows,

$$
\text { Rit }=\frac{(1+X+Y) P i t-\text { Pio }- \text { YPni }+ \text { DPSit }}{\text { Pio }+ \text { YPni }},
$$

where Pni , $X$ and $Y$ represent Par value shares, Percent increase in capital from the reserves and Percent capital increase of receivables and cash earned, respectively. Information technology capital is calculated based on the value of all software packages as well as the hardware equipment purchased for firm. This is calculated by finding the net increase value of these assets in each year. In addition, for normalization purpose, we divide the value by total assets of each year. There are three independent variables including Innovation Capital, Communication Capital and IT Capital and they are calculated as follows,

$$
\begin{aligned}
& \text { Communication capital }=\frac{\text { Average cost of advertisement }}{\text { Revenue }}, \\
& \text { Innovation capital }=\frac{\text { Average cost of } R \& D}{\text { Revenue }}, \\
& \text { Organizational capital }=\frac{\text { Market value of shares }}{\text { Book value of shares }} .
\end{aligned}
$$

To measure intellectual capital, we take a three year average. Finally, there are four control variables associated with the proposed study including capital age (Age), Investment, firm size and leverage. Firm size is calculated by taking natural logarithm on total assets. Other control variables are calculated as follows,

$$
\begin{aligned}
& \text { Age }=\frac{\text { Gross value of equipment }}{\text { Depreciation }}, \\
& \text { Invest }=\frac{\text { Total investment }}{\text { Sales revenue }}, \\
& \text { Leverage }=\frac{\text { Total liabilities }}{\text { Total equities }} .
\end{aligned}
$$

Table 1 demonstrates the summary of some basic statistics

Table 1

Summary of some basic statistics

\begin{tabular}{lcccccc}
\hline Variable & $\mathrm{N}$ & Min & Max & Mean & Standard deviation & Skewness \\
\hline Return & 250 & -0.32 & 0.998 & 0.386 & 0.525 & 0.351 \\
IT capital & 250 & 0.008 & 0.215 & 0.075 & 0.283 & 0.980 \\
Organizational capital & 250 & 1.235 & 8.268 & 3.237 & 1.835 & 1.953 \\
$\begin{array}{l}\text { Communication } \\
\text { capital }\end{array}$ & 250 & 0 & 0.075 & 0.014 & 0.325 & 1.003 \\
Innovation capital & 250 & 0 & & & & \\
Investment & 250 & 0.009 & 0.152 & 0.023 & 0.296 & 0.752 \\
Leverage & 250 & 0.037 & 1.854 & 0.587 & 0.215 & 1.399 \\
Age & 250 & 6.952 & 76.012 & 23.124 & 1.214 & 0.866 \\
Size & 250 & 23.161 & 29.425 & 26.425 & 1.425 & 1.742 \\
\hline
\end{tabular}


The preliminary investigation on basic statistics given in Table 1 has indicated that the data could be normally distributed. Next, we present details of estimating four regression models given in Eq. (1) to Eq. (4).

\section{The results}

In this section, we present details of testing four hypotheses of the survey.

\subsection{First hypothesis: The relationship between IT capital and firms' return}

The first hypothesis of the survey investigates the relationship between information technology capital and firms' return. In our survey, the implementation of Chaw test yields Limmer F-value $=1.695$ (Sig. $=0.637$ ), which means we need to use Pooled data. Table 2 presents the results of regression analysis.

\section{Table 2}

The summary of regression analysis for testing the first hypothesis

\begin{tabular}{|c|c|c|c|c|c|}
\hline Variable & $\beta$ & Standard error & t-value & Sig. & VIF \\
\hline Intercept & -0.259 & 0.296 & -0.875 & 0.381 & \\
\hline IT capital & 0.278 & 0.026 & 3.115 & 0.027 & 1.954 \\
\hline Organizational capital & 0.0004 & 0.0002 & 2.005 & 0.045 & 3.178 \\
\hline Communication capital & 0.061 & 0.021 & 2.902 & 0.004 & 1.651 \\
\hline Innovation capital & 0.024 & 0.012 & 2.017 & 0.044 & 1.763 \\
\hline Investment & 0.002 & 0.008 & 0.315 & 0.752 & 1.983 \\
\hline Leverage & 0.068 & 0.082 & 0.827 & 0.408 & 2.213 \\
\hline Age & 0.017 & 0.026 & 0.667 & 0.505 & 3.450 \\
\hline Size & 0.014 & 0.006 & 2.344 & 0.019 & 2.851 \\
\hline
\end{tabular}

Adjusted R-Square $=0.446 \quad$ F-value $=7.421$ (Sig. $=0.000)$ Durbin-Watson $=1.754$

As we can see from the results of Table 2, F-value is statistically significant, which indicates the relationship between dependent and independent variable is linear. In addition, Durbin-Watson is within the desirable level, which means there is no correlation among residuals. Finally, Adjusted RSquare is equal to 0.446, which means the independent variable could approximately describe 45 percent of the changes on dependent variable. Moreover, t-student value associated with IT capital is statistically significant, which means the independent variable, IT capital, influences positively on firm's return. Therefore, the first hypothesis of the survey has been confirmed.

\subsection{Second hypothesis: The relationship between organizational capital and firms' return}

The second hypothesis of the survey tries to find out the relationship between organizational capital and firms' return. In our survey, the implementation of Chaw test yields Limmer F-value $=1.768$ (Sig. $=0.621$ ), which means we need to use Pooled data. Table 3 gives the results of regression analysis.

Table 3

The summary of regression analysis for testing the second hypothesis

\begin{tabular}{lccccc}
\hline Variable & $\beta$ & Standard error & t-value & Sig. & VIF \\
\hline Intercept & -0.076 & 0.045 & -1.685 & 0.093 & 2.008 \\
IT capital & 0.274 & 0.095 & 2.829 & 0.004 & 3.412 \\
Organizational capital & 0.008 & 0.04 & 1.993 & 0.047 & 1.451 \\
Investment & 0.003 & 0.013 & 0.304 & 0.760 & 1.652 \\
Leverage & 0.045 & 0.092 & 0.489 & 0.624 & 1.624 \\
Age & 0.018 & 0.016 & 1.154 & 0.249 & 2.014 \\
\hline Size & 0.040 & 0.011 & 3.486 & 0.000 & \\
\hline
\end{tabular}

Adjusted R-Square $=0.075 \quad$ F-value $=5.229($ Sig. $=0.000)$ Durbin-Watson $=2.251$ 
As we can see from the results of Table 3, F-value is statistically significant, which indicates the relationship between dependent and independent variable is linear. In addition, Durbin-Watson is within the desirable level, which means there is no correlation among residuals. Finally, Adjusted RSquare is equal to 0.075 , which means the independent variable could approximately describe 7 percent of the changes on dependent variable. Moreover, t-student value associated with organizational capital is statistically significant, which means the independent variable, organizational capital, influences positively on firm's return. Therefore, the second hypothesis of the survey has been confirmed.

\subsection{Third hypothesis: The relationship between communication capital and firms' return}

The third hypothesis of the survey investigates the relationship between communication capital and firms' return. In our survey, the implementation of Chaw test yields Limmer F-value = 2.111 (Sig. = 0.549), which means we need to use Pooled data. Table 4 provides the results of regression analysis.

\section{Table 4}

The summary of regression analysis for testing the third hypothesis

\begin{tabular}{lccccc}
\hline Variable & $\beta$ & Standard error & t-value & Sig. & VIF \\
\hline Intercept & -0.077 & 0.044 & -1.724 & 0.085 & 0.004 \\
IT capital & 0.108 & 0.037 & 2.861 & 0.019 & 1.540 \\
Communication capital & 0.042 & 0.018 & 2.341 & 0.166 & 1.756 \\
Investment & 0.006 & 0.004 & 1.385 & 0.498 & 1.820 \\
Leverage & 0.037 & 0.054 & 0.675 & 0.857 & 1.145 \\
Age & 0.016 & 0.091 & 0.179 & 0.043 & 2.123 \\
Size & 0.021 & 0.010 & 2.056 & & 2.685 \\
\hline
\end{tabular}

Adjusted R-Square $=0.191 \quad$ F-value $=7.844($ Sig. $=0.000)$ Durbin-Watson $=1.740$

As we can see from the results of Table 4, F-value is statistically significant, which indicates the relationship between dependent and independent variable is linear. In addition, Durbin-Watson is within the desirable level, which means there is no correlation among residuals. Finally, Adjusted RSquare is equal to 0.191 , which means the independent variable could approximately describe 19 percent of the changes on dependent variable. Moreover, t-student value associated with IT capital is statistically significant, which means the independent variable, communication capital, influences positively on firm's return. Therefore, the third hypothesis of the survey has been confirmed.

\subsection{Fourth hypothesis: The relationship between innovation capital and firms' return}

The fourth hypothesis of the survey investigates the relationship between innovation capital and firms' return. In our survey, the implementation of Chaw test yields Limmer F-value $=1.252$ (Sig. $=0.740)$, which means we need to use Pooled data. Table 5 shows the results of regression analysis.

\section{Table 5}

The summary of regression analysis for testing the fourth hypothesis

\begin{tabular}{lccccc}
\hline Variable & $\beta$ & Standard error & t-value & Sig. & VIF \\
\hline Intercept & -0.068 & 0.045 & -1.524 & 0.129 & \\
IT capital & 0.178 & 0.081 & 2.282 & 0.029 & 1.657 \\
Innovation capital & 0.023 & 0.004 & 5.663 & 0.000 & 1.356 \\
Investment & 0.001 & 0.003 & 0.446 & 0.655 & 2.003 \\
Leverage & 0.043 & 0.022 & 1.935 & 0.051 & 1.198 \\
Age & 0.012 & 0.017 & 0.688 & 0.491 & 2.532 \\
Size & 0.020 & 0.009 & 2.029 & 0.043 & 2.603 \\
\hline
\end{tabular}

Adjusted R-Square $=0.101 \quad$ F-value $=3.053$ (Sig. $=0.000)$ Durbin-Watson $=2.085$ 
As we can see from the results of Table 5, F-value is statistically significant, which means the relationship between dependent and independent variable is linear. In addition, Durbin-Watson is within the desirable level, which means there is no correlation among residuals. Finally, Adjusted RSquare is equal to 0.101, which means the independent variable could approximately describe 10 percent of the changes on dependent variable. Moreover, t-student value associated with innovation capital is statistically significant, which means the independent variable, innovation capital, influences positively on the firm's return. Therefore, the last hypothesis of the survey has been confirmed.

\section{Conclusion}

In this paper, we have presented an empirical investigation to study the effects of various capitals on firm performance on a sample of firms listed on Tehran Stock Exchange. The proposed study has applied some linear regression models to examine the hypotheses of the survey. The results have indicated that there were some positive and meaning relationships between human capital, innovation capital, communication capital and information technology capital and firms' return, however, each of these four factors had various effect. In addition, the study has detected that communication capital maintained the highest impact on firms' return. Recent surveys have shown that people are more interested in measuring the effects of human capital intensity on firms' performance. In addition, the results of our survey have indicated that investing in information technology could play essential role for development of firms.

\section{Acknowledgement}

The authors would like to thank the anonymous referees for constructive comments on earlier version of this paper.

\section{References}

Arvanitis, S., \& Loukis, E. N. (2009). Information and communication technologies, human capital, workplace organization and labour productivity: A comparative study based on firm-level data for Greece and Switzerland. Information Economics and Policy, 21(1), 43-61.

Badertscher, B. A. (2011). Overvaluation and the choice of alternative earnings management mechanisms. The Accounting Review, 86(5), 1491-1518.

Brown, S., Hillegeist, S. A., \& Lo, K. (2009). The effect of earnings surprises on information asymmetry. Journal of Accounting and Economics, 47(3), 208-225.

Blundell, R., Dearden, L., Meghir, C., \& Sianesi, B. (1999). Human capital investment: the returns from education and training to the individual, the firm and the economy. Fiscal studies, 20(1), 1-23.

Bontis, N., \& Fitz-Enz, J. (2002). Intellectual capital ROI: a causal map of human capital antecedents and consequents. Journal of Intellectual capital,3(3), 223-247.

Lööf, H., \& Heshmati, A. (2002). Knowledge capital and performance heterogeneity: A firm-level innovation study. International Journal of Production Economics, 76(1), 61-85.

Lin, Y. M., Lee, C. C., Chao, C. F., \& Liu, C. L. (2015). The information content of unexpected stock returns: Evidence from intellectual capital. International Review of Economics \& Finance, 37, 208225.

Rhodes-Kropf, M., Robinson, D. T., \& Viswanathan, S. (2005). Valuation waves and merger activity: The empirical evidence. Journal of Financial Economics, 77(3), 561-603.

Wang, W. Y., \& Chang, C. (2005). Intellectual capital and performance in causal models: Evidence from the information technology industry in Taiwan. Journal of intellectual capital, 6(2), 222-236.

Watts, R. L., \& Zimmerman, J. L. (1990). Positive accounting theory: a ten year perspective. Accounting review, 65(1), 131-156. 